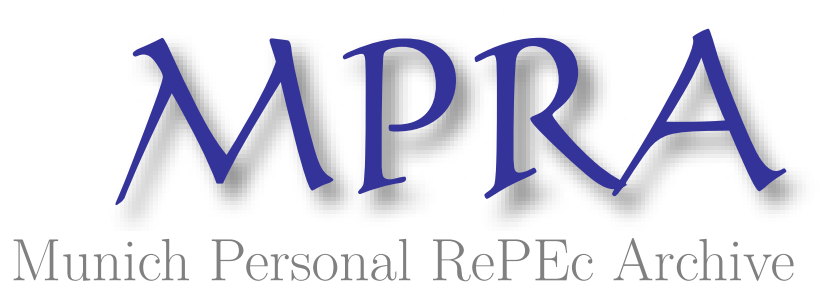

\title{
Do Credit Constraints Matter more for College Dropout Entrepreneurs?
}

\author{
Werner, Arndt \\ IfM Bonn \\ 1 November 2008
}

Online at https://mpra.ub.uni-muenchen.de/11867/

MPRA Paper No. 11867, posted 02 Dec 2008 09:39 UTC 


\title{
Do Credit Constraints Matter more for College Dropout Entrepreneurs?
}

\author{
Arndt Werner \\ Institute for Small and Medium Size Enterprises, \\ Bonn, Germany
}

\begin{abstract}
Start-ups and their respective market partners are faced with severe problems of asymmetric information due to their lack of prior production history and reputation. Given this situation, it is most likely that outside financiers will not be informed about the potential gains, losses, and risks of the new venture. In our paper, we study how banks screen the abilities of the entrepreneurs. We argue that specific characteristics of the educational history of individuals signal their quality as founders. Namely, we expect banks to also use "college dropout" as an indicator when deciding to extend credit to a founder. We empirically test our hypotheses using a dataset of 189 German start-ups collected in 1998/99. Our hypothesis is borne out by the data. Applying ordered probit techniques we find that college dropouts have more difficulties to obtain the credit they need in the beginning of their start-up than those without college dropout experience.
\end{abstract}

KEYWORDS: adverse selection, financial constraints, entrepreneurship, education

JEL CLASSIFICATION: M13, M5, D82, M21

- Dr. Arndt Werner, Institute for Small and Medium Size Enterprises, Bonn (IfM Bonn), Maximilianstr. 20, 53111 Bonn, Germany. Tel.: +41 (0)49 22872997 44, Fax: +41 (0)49 22872997 34, E-Mail: werner@ifmbonn.org. The IfM Bonn is associated to the University of Cologne, Germany 


\section{Do Credit Constraints Matter more for College Dropout Entrepreneurs?}

\section{Introduction}

Start-ups are often seen as an important factor in economic growth and job creation (Birch, 1979; Acs and Audretsch, 1990; Storey and Tether, 1996). However, entrepreneurial activity is often hampered by limited access to financial resources (e.g. Evans and Jovanovic, 1989; Lindh and Ohlson, 1996; Blanchflower and Oswald, 1998). Banks hesitate to lend funds to new businesses because of capital market imperfections (Ang, 1991, 1992; Blumberg and Letterie, 2008). Outside financiers of a start-up usually have no relevant data about production facilities, processes, or product markets to use as benchmarks in evaluating a proposed business plan. Therefore, the value of a start-up project is difficult to judge, even for the most experienced of creditors. As a consequence, the asymmetric information gap between the founder of new firm and the creditor is likely to be extraordinarily large, potentially causing problems like credit rationing. ${ }^{\mathrm{i}}$ Creditors may finance only a fraction of assets and operations, claim high collateral, or shorten the length of their loans. Put differently, they might find investments in a start-up particularly risky, given the lack of history, reliable benchmarks, and prior reputation. To reduce the probability of a start-up becoming a failure, creditors of new ventures must find ways to overcome the initial problem of asymmetric information, i.e. find indicators that the founder will run their new venture successfully (see e.g. Binks and Ennew, 1996; Egeln et al., 1997; Falk, 1999).

The objective of our paper is to determine whether specific characteristics of the educational history of the founder can help creditors to solve or reduce this credit market problem. Using a screening design as the theoretical framework, we argue that creditors can assess the quality of the new venture by screening the educational biography of the founders. Since creditors cannot readily observe the quality of the new venture directly, they have an incentive to approximate that information via reliable indicators which correlate with their ex ante unobservable entrepreneurial productivity. According to our theoretical considerations we expect creditors to draw on "college dropout" as a quality signal when deciding upon start-up credit for a founder. Although there may also be other ways for highly productive entrepreneurs to signal the above average quality of their venture, such as collateral or bonds, we do not consider them to be a complete substitute for educational indicators but rather 
complementary instruments, because in the special situation start-ups they are not available, or not to a sufficient degree (see Parker, 2004 for examples).

To test our screening assumptions we use German firm level data collected in 1998/99, containing 189 start-ups which were founded between 1992 and 1997 in the Cologne area. All predictions are borne out by the data, leading us to conclude that screening for educational characteristics is an effective instrument for reducing the problems of asymmetric information on the credit market for new ventures.

Note that the models specified and tested in our paper concentrate on access to debt capital and the impact of educational characteristics to reduce the difficulties to obtain the credit the founders need for their start-ups. Thus, our study is in line with previous research of Bates (1990), Storey (1996), Binks and Ennew, 1996, Blumberg and Letterie (2004) or Astebro and Bernhardt (2005). This paper is not concerned with new venture performance (e.g. survival duration, business profits, etc.) and direct effects on financial or human capital (see here for example Evans and Jovanovic, 1989; Cooper et al.,1994; Holtz-Eakin, Joulfaian and Rosen, 1994; van Praag, 2003, Moog and Backes-Gellner, 2003 or Bosma et al., 2004, Parker and van Praag 2005).

The rest of the paper is organized as follows. In the next section we summarize the literature and derive some empirically testable hypotheses. In the third section on "Data, Measurement Issues, and Methodology" we describe our data set and discuss measurement and methodological issues. In the fourth section we present our econometric results; and finally, we summarize and draw some tentative conclusions.

\section{Literature and hypothesis}

To date, many papers focus on the efficiency of debt-financed ventures in general, and on credit rationing or under-investment in start-ups in particular. One strand of these papers assumes the existence of credit rationing and concentrates either on the causes of credit rationing ${ }^{\mathrm{ii}}$, on the effects of credit rationing on efficiency, or on the effects of corrective government actions on credit rationing (see Parker, 2004, sec. 5 for a survey of the literature). A second strand of papers argues that it is possible to eliminate credit rationing by using various instruments to reveal hidden quality information. These instruments range from reputation through relationship banking, signaling and/or screening to using collateral and 
bonds. Examples of screening by banks offering a menu of contract options include collateral (cf. Bester, 1985), joint liability under group lending (cf. Ghatak and Guinnane, 1999); offering limited and unlimited liability debt contracts to entrepreneurs (cf. Chamley, 1983) and offering a high initial interest rate in a multi-period setting (cf. Webb, 1991; Boot and Thakor, 1994).

Our paper is embedded in this second strand of literature. We argue that most of the instruments that reveal hidden information are unsuitable for start-ups since the business idea and the company is both totally new, there is no reputation or experience to build on.

Sufficient collateral for example is often beyond the means of a typical founder and therefore banks often cannot even use extended collateral as a screening mechanism (Parker, 2004). In addition, lenders usually rely on 'carcass' evaluation and refrain from thoroughly screening every single entrepreneur's credibility as this is unlikely to be cost effective. Ravid and Spiegel (1997) for example argue that start-ups in particular are too small and complex, economies of scale are non existent and therefore thorough individual screening does not pay. However, screening the educational biography of the founder is a plausible way of dealing with the information asymmetries of entrepreneurs, as it is cost-efficient and implies using a persons past behavior in other activities, namely higher education, to draw conclusions about their future productivity in a new venture.

The role of educational characteristics for entrepreneurs has rarely been analyzed in depth, despite some early mentions in the economics literature. In the late 1970s there was a first discussion on how the educational degrees of employees vs. entrepreneurs could be used to test the educational screening hypothesis (cf. Wolpin, 1977; Lazear, 1977; or more recently, Lofstrom, 2000). Lazear (1977) for example has argued that educational characteristics might not be irrelevant for entrepreneurs because customers may use their credentials as a signal in assessing product quality. This argument has been systematically followed up recently by Backes-Gellner and Werner (2007). They show that innovative entrepreneurs signal their quality by means of certain characteristics of their educational history, namely entrepreneur's university degree and the actual length of university study. Parker and van Praag (2005) also study how the performance of a start-up is affected by capital constraints and human capital. According to their model, in the case of unobserved ability lenders use a common screening technology to assess ability and therefore rate all lenders with the same error, in the case of observed ability, lenders assess and classify ability by certified human capital (i.e. years of schooling), which is assumed to perfectly reflect ability. Parker and van Praag (2005) show 
that under the assumption that physical capital and human capital are not complements, greater human capital decreases borrowing constraints.

Yet, not all educational characteristics can serve alike as reliable productivity indicators. As shown by Spence (1973) initially there are several conditions that have to be met in order for an educational indicator to be able to guarantee a separating equilibrium, i.e. in our case an equilibrium which reliably separates entrepreneurs with high probability of success from entrepreneurs with low probability of success. First, the indicator must be closely related to the type of ability that is required of founders and makes them more likely to be successful with their new venture. Thus, the question that needs answering is what the ability requirements of firm founders and the requirements in the educational system are? As shown in a number of empirical studies, new venture markets are characterized by rapid technological change, short product life cycles, and rather volatile market conditions (see e.g. McDermott and O'Connor, 2002). Founders who want to survive in such an environment must be able to work continuously and rapidly through a large amount of new market information, quickly and efficiently filtering out what is important and flexibly deriving new solutions. Given this environment, a founder needs analytical and problem-solving skills, self-direction, and endurance (Lück and Böhmer, 1994). Now within the German educational system it is common knowledge that these general analytical and problem-solving skills are the ones required for university studies. They are considered to be indispensable for obtaining a university degree. We assume that college dropouts genuinely do not have these general analytical and problem-solving skills. Thus, compared to founders with a university degree or even compared to some other kind of occupational degree (and not having withdrawn from university) we assume college dropouts to run a start-up less successfully. Furthermore, the failure rate at German universities is quite high, making it very expensive for "low ability" students to complete studies for a university degree. In 2002 for example, the average failure rate was about 25 percent across all fields and universities (IWD, 2002). Thus, the cost for low ability students to obtain a university degree literally extends to infinity.

However, a person's educational history can only serve as a signal if it is available to the market partner looking for a screening device to overcome asymmetric information. Thus, it is necessary to determine whether banks as lenders can screen the founder's educational history in a cost-efficient way. Now Empirical studies show that commercial banks always use a number of screening devices to evaluate a start-up, among which a detailed business plan is indispensable (Egger and Gronemeier, 1999). A successful business plan provides detailed 
information about the loan applicant via a CV showing educational institutions, fields and dates of study, and degrees (not) earned. Therefore, if banks consider being a college dropout as valuable information, they can easily obtain it and use it for their credit decision.

To summarize, we expect the data to confirm that college dropout founders to have more problems obtaining the credit they ask for than founders without college dropout experience.

\section{Data, Measurement Issues, and Methodology}

To test our predictions about educational screening of banks, we analyze dataset of 189 startups in the Cologne area. The data were collected in 1998/99 in a project on regional determinants and effects of entrepreneurship and cover a representative sample of start-ups

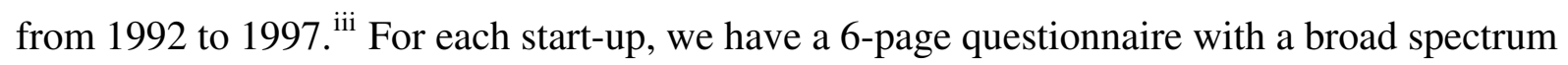
of questions on the founder and his or her personal background (education, experience), the economic background of the start-up (sources and difficulties obtaining start-up capital), its current financial situation, human resources issues, production technology, networks, and social capital (for more details on the Cologne Founder Study, see Backes-Gellner, Demirer, and Moog, 2000). Almost two thirds of the start-ups are in the service sector (62 percent); a quarter is in retailing, and 13 percent are in manufacturing. 20 percent of the start-ups are innovative start-ups, while the rest are traditional start-ups. The founders were predominantly male (87 percent), 35 years old on average, and often highly qualified (35 percent held a university degree and 12 percent a doctoral degree).

\section{Dependent Variable}

There are several ways how credit constraints can be measured. Previous research has tended to use indirect indicators of wealth, inheritance or windfall gains to test the effect of captal constraints on performance (Evans and Jovanovic, 1989; Black, de Meza and Jeffreys, 1992, Holtz-Eakin et al., 1994, Lind and Ohlsson, 1996). A positive correlation between wealth and entrepreneurship performance is said to indicate capital constraints. The drawback of these approaches is that they do not reveal whether the entrepreneurs were basically able to obtain external capital if needed. Parker and van Praag (2005) construct a measure of capital constraints in which the total amount of capital used at the start of the new business is related to the amount of capital required. Although we do not have hard facts on the amount or the conditions of our founders' credit, we do have a very good indirect indicator that should 
reflect all these aspects simultaneously. In our survey, founders were asked whether, during their start-up phase, it was difficult to obtain the credit they initially needed for their start-up. They answered using a 5-point Likert scale from $1=$ very problematic to $5=$ not at all problematic. It is important to note that our rating of the credit problems does not refer to the current situation in the company but to the situation at the beginning of the start up. In using a subjective rating we assume that less favorable hard facts will be reliably reflected in a lower subjective evaluation score. Such an assumption is supported by Binks and Ennew (1996), who argue that a subjective classification is a useful proxy for credit constraints because individual difficulties in obtaining credit correspond to unfavorable credit conditions. Moreover, Van Praag (2003) uses a direct individual indicator for initial credit constraints which is very similar to ours ("Did you experience problems in obtaining sufficient (external) capital at the start of your venture?'). On the other hand, Parker (2004) points out that claims by survey respondents that they face(d) credit constraints should be treated with some caution because they are prone to self-serving bias whereby entrepreneurs might blame banks for inherent shortcomings. However, since our respondents were asked a few years after start-up time, we assume that this bias had dissipated by the time of our survey. A subjective indicator, furthermore, has the advantage of capturing various kinds of constraints in just one indicator. On the basis of a large German data set, Egeln, Licht, and Steil (1997) for example find a very strong correlation between a firm's self-classification of credit problems and the official rating given by Creditreform, Germany's largest credit-rating agency. Thus, altogether we are confident that a subjective rating of credit problems during the start-up phase reliably identifies the real credit problems of the start-up. ${ }^{\text {iv }}$

\section{Major Explanatory Variable}

To test our main hypothesis we include as our major explanatory variable we include a dummy variable taking the value 1 if the founder is a college dropout, otherwise 0 .

Fortunately, our data contains the information if the founder has studied at a university in the past, but dropped out for good without finishing his studies.

\section{Control Variables}

As mentioned before, banks finance promising new business ideas if they can evaluate their potential success properly. A broad literature on successful start-ups offers insight on which factors are relevant for start-up success. Thus, in addition to our major explanatory variable, we use a number of standard control variables which are specified in table 1. 


\section{Table 1}

\section{Description of Variables and their expected Impact on the Difficulty obtaining Start-Up}

Credit

\begin{tabular}{|c|c|c|c|c|}
\hline Variable Name & Variable Description & Mean & Std.dev & $\begin{array}{l}\text { Exp. } \\
\text { Sign }\end{array}$ \\
\hline \multicolumn{5}{|c|}{ Dependent Variable } \\
\hline $\mathrm{CC}$ & $\begin{array}{l}\text { Credit constraints: subjective evaluation of problems obtaining } \\
\text { initial credit }[1=\text { not problematic at all, } 5=\text { very problematic } \\
\text { (measured at the start of the new venture) }]\end{array}$ & 3.08 & 1.49 & \\
\hline \multicolumn{5}{|c|}{ Major Explanatory Variable } \\
\hline DROPOUT & Founders with college dropout experience $[\mathrm{Yes}=1, \mathrm{No}=0]$ & 0.06 & 0.24 & + \\
\hline \multicolumn{5}{|c|}{ Educational Degrees } \\
\hline PHD & Doctoral Degree $[0=$ no; $1=$ yes $]$ & 0.13 & 0.33 & - \\
\hline COLLEGE & $\begin{array}{l}\text { University Degree (Diploma, Magister Artium (M.A.) and other } \\
\text { first degrees as highest educational degree) }[0=\text { no; } 1=\text { yes }]\end{array}$ & 0.35 & 0.48 & - \\
\hline MASTER & Master Craftsman $[0=$ no; $1=y e s]$ & 0.11 & 0.32 & - \\
\hline APPRENT & Apprenticeship training $[0=$ no; $1=$ yes $]$ & 0.34 & 0.48 & $?$ \\
\hline NOVOC & Founders without any vocational training $[0=$ no; $1=$ yes $]$ & 0.07 & 0.24 & + \\
\hline \multicolumn{5}{|c|}{ Other Controls } \\
\hline PARTNER & Start-up with a Partner ? [0=no; $1=$ yes $]$ & 0.37 & 0.48 & - \\
\hline INNOVSU & $\begin{array}{l}\text { Innovative start-up classified by industry at the start of the new } \\
\text { venture (OECD list) }[0=\text { no; } 1=\text { yes }]\end{array}$ & 0.19 & 0.40 & + \\
\hline OWNINV & Founder's Equity Investments (measured in 100,000 Euros) & 0.82 & 4.19 & - \\
\hline DEBTC & Debt capital? [0=no; $1=\mathrm{yes}]$ & 0.48 & 0.50 & - \\
\hline JOBEXP & Prior job experience in the start-up industry $[0=$ no; $1=y e s]$ & 0.77 & 0.42 & - \\
\hline FOUNDEXP & Founding had prior founding experience) $[0=$ no; $1=y e s]$ & 0.25 & 0.43 & $?$ \\
\hline SECONDJ & $\begin{array}{l}\text { Founder has an additional second job in paid employment } \\
{[0=\text { no; } 1=\text { yes }]}\end{array}$ & 0.16 & 0.37 & ? \\
\hline FAGE & Founders' age [measure in 10 years] & 3.54 & 0.83 & $?$ \\
\hline MALE & Founder is male $[0=$ no; $1=$ yes $]$ & 0.87 & 0.33 & $?$ \\
\hline MARRIED & Founder is married $[0=$ no; $1=y e s]$ & 0.54 & 0.50 & - \\
\hline CHILD & Founder has children $[0=$ no; $1=$ yes $]$ & 0.51 & 0.50 & $?$ \\
\hline MANUF & Manufacturing $[0=$ no; $1=$ yes $]$ & 0.15 & 0.36 & $?$ \\
\hline TRADE & Trade $[0=$ no; $1=$ yes $]$ & 0.23 & 0.42 & $?$ \\
\hline SERVICES & Services $[0=$ no; $1=$ yes $]$ & 0.62 & 0.49 & ? \\
\hline
\end{tabular}

${ }^{a}$ Note: Data stem from the Cologne Founder Study (CFS).

First, we expect young and highly educated individuals as well as those with a second job in paid employment to be more likely to have a higher post-failure earning. This, i.e. the earning possibilities after a possible failure of the new venture, should be a good indicator for banks 
whether the business starter can meet his credit obligations in any case. The study of Bates (1990) shows for example that highly educated entrepreneurs are more likely to create firms that stay in operation and, at the same time, that higher education is a major determinant of the financial capital structure of small business start-ups (see also Story, 1994). Thus, in our empirical analyses we distinguish different educational levels based on the educational history of the founder. We differentiate between founders who hold a doctoral degree as their highest university degree, founders who hold a standard university degree, such as a Diploma, a Master's or Magister Artium, founders who never received a university degree, but apprenticeship training or master craftsman training as their highest vocational degree. The reference group consists of the founders with no vocational training whatsoever. As mentioned above, we also include age (measured in years) and having a second job. Yet, because lenders may be more willing to lend to older, more experienced founders and because having a second job requires time which cannot be invested in the new venture, we expect the effect of age and second job to remain unsettled. We also include team venture start-up in our models because we expect multiple ownership to facilitate access to bank loans. To cope with everyday challenges founders need specific knowledge about technological details, products and processes which they quickly combine with information about commercial opportunities and economic or legal constraints (e.g. Shane and Venkataraman, 2000). This, in turn, requires a broad set of skills, aptitudes, and insights which are rarely encountered in one single person. Cooper, Gimeno-Gascon and Woo (1994) or Backes-Gellner, Mohnen and Werner (2007) for example show, the presence of partners can help to overcome these start-up challenges. Furthermore, we also include the amount of personal equity capital because own investments should mitigate principal-agent conflicts between banks and lenders. The more a business owner will commit own resources to the venture, the better a bank should be convinced that they are investing in a serious idea (Blumberg and Letterie, 2008). We also differentiate between innovative and traditional start-ups. We believe that founders of innovative start-ups respective their market partners are faced with even stronger asymmetric information problems than founders of traditional start-ups due to the fact that in former virtually no prior history of comparable cases exist whatsoever. In a first instance, this should make it more difficult to overcome credit constraints for innovative start-ups (Backes-Gellner and Werner, 2007). Further, several studies show that demographic characteristics and the social background of the founder is related to success (see Parker 2004 for an overview). Married individuals are more likely to become successful entrepreneurs because their spouses 
offer them financial and emotional support. Yet, we expect the effect of children on financial access to be unsettled because children may require money and time which cannot be invested in the new venture. Research on gender reveals differences in risk preference between males and females with females being more risk adverse entrepreneurs (Wagner, 2007).

Conventional wisdom asserts that a entrepreneur has to make risky decisions in uncertain environments to become successful (Khilstrom and Laffont, 1979). On the other hand, recent empirical research with focus on the question if individuals face difficulties in raising funds from financial institutions when starting a business show no credit discrimination based on gender (e.g. Storey, 1994). Thus again, we expect the effect of gender to be unsettled. We also include business ownership experience. Business ownership experience reveals a good deal about the competence of the founder and according human capital theory, those with entrepreneurial experience should perform better than others. In reality, however, not all types of experience indicate enhanced knowledge alone. The experience of failure, for example, might equally be a signal for entrepreneurial weakness and, thus, an argument for banks not to give any funds to the founder (Werner and Kay, 2006). Unfortunately, we are not able to differentiate between founders with successful and unsuccessful entrepreneurial experience. Consequently, we also expect the effect of business ownership experience to stay unsettled. Furthermore, Blumberg and Letterie (2008) show that experience obtained in previous jobs affect access to external financial resources. As a consequence we include previous job experience in our models. Finally, all regressions include dummies indicating economic sectors (manufacturing, trade, services) and founding year (1992-1997) to catch different industry and time cycle effects.

\section{Empirical Results}

To test our credit market implications, we use an ordered probit model. ${ }^{\mathrm{v}}$ The dependent variable should be interpreted as follows: the higher the subjective credit problem indicator, the more difficulty the founder experienced obtaining the required credit during the start-up phase (the situation is worse); the lower the indicator, the easier it was to obtain the required credit (the situation is better). Table 2 displays the results for three different models. ${ }^{\mathrm{vi}}$ 
Table 2

Ordered probit regression results: College Dropouts and credit market constraints

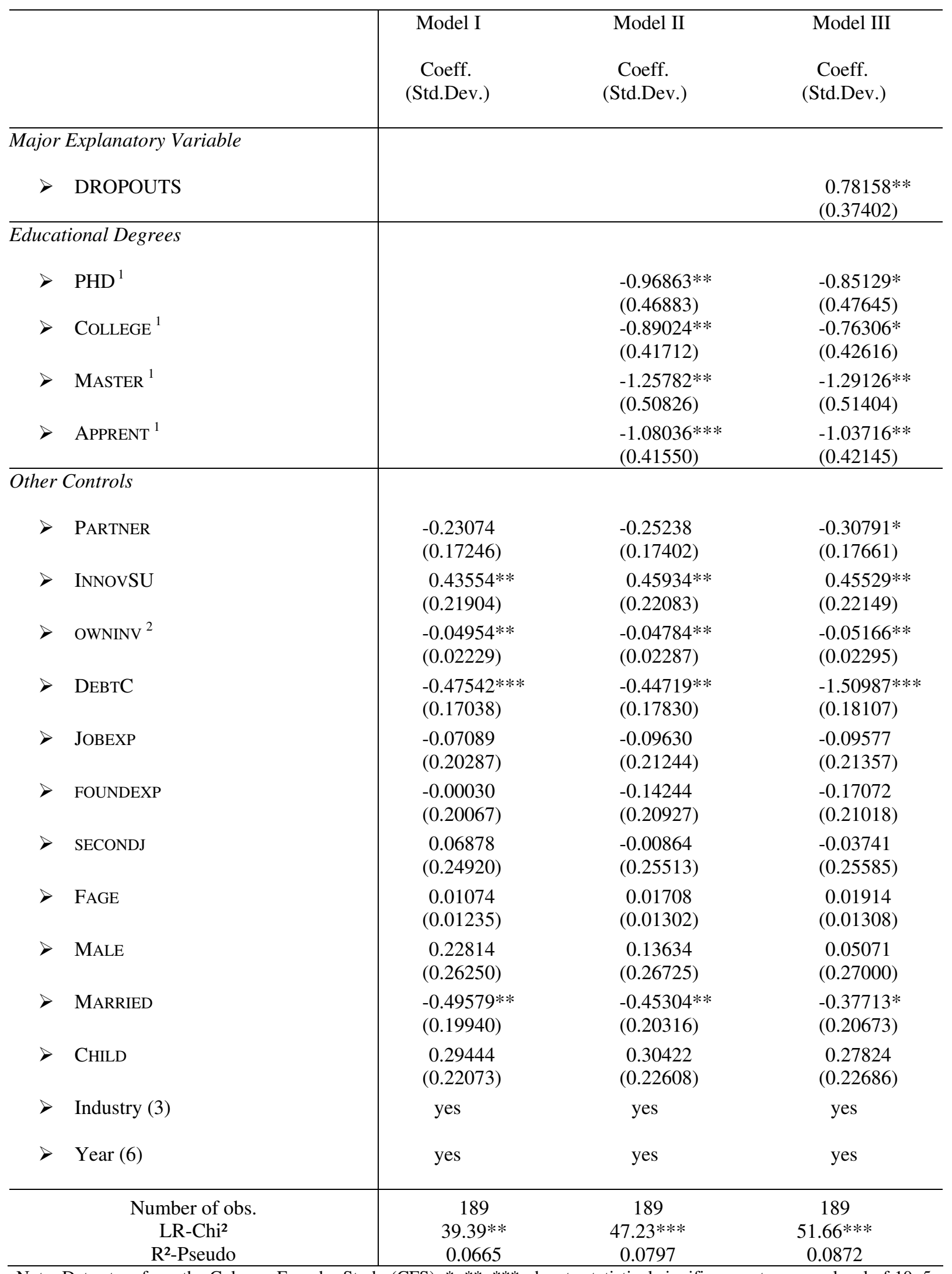

Note: Data stem from the Cologne Founder Study (CFS). *, **, *** denote statistical significance at an error level of 10, 5 , and 1 percent. ${ }^{1}$ Reference: founders without any vocational training. ${ }^{2}$ Logarithm of Founder's Equity Investments 
In a first model, we use a specification that includes only the vector of control variables that was described in Table 1. In a second model, we include the educational degrees and in a third model, we also include our explanatory variable of interest, i.e. if the founder has dropped out of college or not. Our hypothesis that college dropout founders to have more problems obtaining the credit they ask for than founders without college dropout experience is borne out by the data. We find that credit problems are significantly worse for college dropouts which is in accordance with our assumption that banks use this information to reduce information asymmetry for start-up credits (see model III). Furthermore, an incremental F-test clearly indicates that the variable DROPOUT adds explantory power to our model $\left(\mathrm{X}^{2}=4.37\right.$; $d f=1$, Prob $<0.0366$ ) which confirms the relevance of DROPOUT added in model III.

Table 3

Individual Predicted Probabilities: College Dropout Experience

\begin{tabular}{|c|c|c|c|c|c|c|}
\hline \multirow{2}{*}{\multicolumn{2}{|c|}{ Ideal Type }} & \multicolumn{5}{|c|}{ Outcome Category (difficulty to obtein start-up credit) } \\
\hline & & 1 & 2 & 3 & 4 & 5 \\
\hline & $\begin{array}{l}\text { An "average individual" with college dropout } \\
\text { experience }\end{array}$ & 0.056 & 0.057 & 0.199 & 0.202 & 0.486 \\
\hline$>$ & $\begin{array}{l}\text { An "average individual" without college } \\
\text { dropout experience }\end{array}$ & 0.211 & 0.123 & 0.280 & 0.179 & 0.207 \\
\hline
\end{tabular}

Note: Data stem from the Cologne Founder Study (CFS). ${ }^{i} 1=$ not at all problematic to $5=$ very problematic

Last but not least, table 3 shows the results of predicted probabilities for "avarage" individuals with and without college dropout experience, i.e. we report the discrete change in the dummy variable DROPOUT evaluated at the multivariate means of the control variables. We can show that, on the one side, the probability of being in the highest category of our dependent variable (i.e. subjective evaluation of great difficulties obtaining initial start-up credit from banks) is $48.6 \%$ for college dropouts, but only $20.7 \%$ for those without dropout experience. On the other side, for college dropouts the predicted probability of being in the lowest category (i.e. having no difficulties at obtaining the credit initially needed) is only $5.7 \%$, yet $21.1 \%$ for those without dropout experience.

Thus, we can conclude that college dropout experience is not only significant, but has a strong effect on credit availability for founders. Withdrawing from higher education makes it more 
difficult to obtain credit, which supports our assumption that banks use college dropout experience as a screening device to evaluate the unobservable inherent quality of the new venture. Because banks cannot build that much on experience and prior information or reputation, they also use the fact that people withdraw from higher education as an educational signal when deciding upon credits.

As for our control variables, in line with prior research we find that banks obviously use multiple signals if available (e.g. Storey, 1994; Blumberg and Letterie, 2008). We find that higher education (i.e. those with expected higher post-failure earnings), multiple ownership, ressource commitment, debt capital and being married seem to convince banks that they are investing in good projects. Thus, it makes it easier for these people to obtain credit. Contrary, founders of innovative start-ups seem to have more difficulties to obtain the credit they need than traditional start-ups in the beginning of their start-up due to the fact that banks are faced with even stronger asymmetric information problems in this case. All other control variables are not significant on any conventional level which is mostly in line with previous literature and thus a rather unspectacular result.

\section{Conclusion}

The purpose of the study at hand was to shed light on the relationship between educational indicators and bank's entrepreneurial financing. The vast majority of small firms and business start-ups relies on commercial banks for obtaining the financial funds they need (Keasey and Watson, 1992; Werner, 2007). Yet, start-ups are faced with the problem that there is no prior history of similar production or business processes. As a result, start-ups, and their market partners are faced with severe problems of asymmetric information. In our paper, we have focused on the question if screening can solve or or substantially reduce these information problems and thereby increasing the potential success of start-ups. We focus our analysis on credit market problems because it has been shown in literature that these are crucial to the success of start-ups, i.e. shortage of credit in the early start-up phase (Parker, 2004). We assume that banks search for credible indicators to evaluate their quality of the new venture. We have argued that most of the instruments that reveal hidden information are unsuitable for start-ups since the business idea and the companies itself are both new. Yet, while there is no reputation or experience to build on, we show evidence that screening the educational biography of the founder is one plausible way of banks to deal with the information 
asymmetries of entrepreneurs - namely college droupout experience. Based on screening theory, we provide empirical evidence that college dropout founders to have more problems obtaining the credit they ask for than founders without college dropout experience. We tested our hypotheses using a dataset of 189 start-ups collected in and around Cologne in 1998/99. Consistent with what we expected, we find that college dropouts have a more problems obtaining the credit they initially need to start their venture.

To summarize, in the paper we have shown that screening for educational characteristics can be a powerfull instrument for banks to cope with typical problems of asymmetric information in start-up credit markets - an aspect which has rarely been analyzed due to a lack of adequate data. Fortunately, we dispose of a unique database covering not only a wide range of variables on the newly founded enterprises but also on the founders and their educational background and personal history.

It should be noted however, that our study has some limitations, which should be kept in mind when considering our results. On the one side, we rely on self-reported measures. Especially our subjective rating as an indicator of credit problems in the beginning of the new venture is controversial in literature. On the other side, our research design is retrospective and, thus, prone to recall bias. Yet, even when keeping these limitations in mind, we are very confident that our results indicate the important role educational screening can play in the early stages of entrepreneurship financing. Last but not least, the quality of our estimations is supported by the results of our control variables, which are in line with prior research results. 


\section{References}

Acs, Z. J. and D. B. Audretsch, 1990, Innovation and Small Firms, Cambridge: MIT Press.

Ang, J.S., 1991, 'Small Business Uniqueness and the Theory of Financial Management', Journal of Small Business Finance 1, 1-13.

Ang, J.S., 1992, 'On the Theory of Finance for Privately held Firms', Journal of Banking and Finance 1, 185-203.

Astebro, T., I. Bernhardt, 2005, 'The Winner's Curse of Human Capital'. Small Business Economics, 24, 63-78.

Backes-Gellner, U., G. Demirer and P. Moog, 2000, 'Hochschulinduzierte Gründungen im Kontext der Gründungsforschung: Grenzen und Lösungsmöglichkeiten einer empirischen Analyse', in D. Bögenhold (eds.), Kleine und Mittlere Unternehmen im Strukturwandel, Frankfurt am Main: Peter Lang Verlag, 123-140.

Backes-Gellner, U., Mohnen, A., and A. Werner, 2007, 'Peer Pressure and Freeriding in Small Ownership Teams - is there an Optimal Size of Start-Up Teams?' ISU Working Paper 54

Backes-Gellner, U. and A. Werner, 2007, 'Entrepreneurial Signaling via Education: A Success Factor in Innovative Start-Ups', Small Business Economics, 29, 173-190.

Bates, T., 1990, 'Entrepreneur Human Capital Inputs and Small Business Longevity', Review of Economics and Statistics, 72, 551-559.

Bester, H. (1985), 'Screening vs. Rationing Credit Markets', American Economic Review, 75, 850-855.

Besanko, D. and A.V. Thakor, 1987, 'Collateral and Rationing: Sorting Equilibria in Monopolistic and Competitive Credit Markets', International Economic Review, 28, 671689.

Binks, M. R. and C. T. Ennew, 1996, 'Growing Firms and the Credit Constraint', Small Business Economics, 8, 17-25.

Birch, D. L., 1979, The Job Generation Process, Cambridge: M.I.T. Program on Neighbourhood and Regional Change.

Black, J., D. De Meza and D. Jeffreys, 1992, House Prices, the Supply of Collateral and the Enterprise Economy, Discussion Paper in Economics Nr. 92/08, University of Exeter.

Blanchflower, D.G. and A.J. Oswald, 1998, 'What makes an Entrepreneur?', Journal of Labor Economics, 16, 26-60.

Blumberg, B.F. and W.A. Letterie, 2008, 'Business Starters and Credit Rationing', Small Business Economics, 30, 187-200.

Boot, A.W.A. and A.V. Thakor, 1994, ,Moral Hazard and Secured Lending in an Infinitely repeated Credit Market Game', International Economic Review, 35, 899-920.

Bosma, N., M. van Praag, R. Thurik and G. de Wit, 2004, ,The Value of Human and Social Capital Investments for the Business Performance of Startups', Small Business Economics, 23, 227-236.

Cooper, A.C., F.J. Gimeno-Gascon and C.Y. Woo, 1994, 'Initial Human and Financial Capital as Predictors of New Venture Performance', Journal of Business Venturing 9, 371-395. 
De Meza, D and D.C. Webb, 1987, 'Too much Investment: A Problem of Asymmetric Information', Quarterly Journal of Economics, 36, 281-292.

Egeln, J., G. Licht and F. Steil, 1997, 'Firm Foundations and the Role of Financial Constraints', Small Business Economics, 9, 137-150.

Egger, U. P and P. Gronemeier, 1999, Existenzgründung, Wiesbaden: Gabler Verlag.

Evans, D. S. and B. Jovanovic, 1989, 'An Estimated Model of Entrepreneurship Choice under Liquidity Constrains', Journal of Political Economy, 97, 808-828.

Ghatak, M and T.W. Guinnane, 1999, The Economics of Lending with Joint Liability: Theory and Practice, Journal of Development Economics, 60, 195-228.

Holtz-Eakin, D.; Joulfaian, D.; Rosen, H. S. (1994): Sticking it out: Entrepreneurial Survival and Liquidity Constraints. Journal of Political Economy 102: 1, pp. 334-347.

Informationsdienst des Instituts der deutschen Wirtschaft (IWD), 2002, 'StudienabbrecherDie Puste ausgegangen', IWD, 49, 2.

Keasey, K. and R. Watson, 1993, Small Firm Management. Ownership, Finance and Performance, Oxford, Blackwell.

Lazear, E. P., 1977, 'Academic Achievement and Job Performance: Note', American Economic Review, 67, 252-254.

Lind, T. and H. Ohlsson, 1996,'Self-Employement and Windfall gains: Evidence from Swedish Lottery', The Economic Journal, 106, 1515-1526.

Long, J.S. and J. Freese, 2003, Regression Models for Categorial Dependent Variables, Revised Edition. Stata Press.

Lofstrom, M., 2000, 'A Comparison of the Human Capital and Signaling Models: The Case of the Self-Employed and the Increase in the Schooling Premium in the 1980's", Discussion Paper 160, Institute for the Study of Labor, Bonn.

Lück, W. and A. Böhmer, 1994, 'Entrepreneurship als wissenschaftliche Disziplin in den USA', Zeitschrift für betriebswirtschaftliche Forschung, 46, 403-421.

McDermott, C. M. and G. C. O'Connor, 2002, 'Managing Radical Innovation: An Overview of Emergent Strategy Issues', Journal of Product Innovation Management, 19, 424-438.

Moog, P. and U. Backes-Gellner, 2003, When do start-ups grow? Academy of Management AoM Conference, August 5th 2003, Seattle.

Parker, S.C., 2004, The Economics of Self-Employment and Entrepreneurship, Cambridge, University Press.

Parker, S. C. and van Praag, M., 2005, 'Schooling, Capital Constraints and Entrepreneurial Performance', Tinbergen Institute Discussion Paper No. TI 2004-106/3.

Ravid, S. and M. Spiegel, 1997, 'Optimal Financing Contracts for a Start-up with Unlimited Operating Discretion', Journal of Financial and Quantitative Analysis, 32, 269-286.

Shane, S., and Venkataraman, S., 2000, 'The Promise of Entrepreneurship as a Field of Research', Academy of Management Review 25, 217-226.

Spence, M., 1973, 'Job Market Signaling', Quarterly Journal of Economics, 87, 355-374.

Stiglitz, J. and A. Weiss, A., 1981, 'Credit Rationing in Markets with Imperfect Information'. American Economic Review, 71, 393-410. 
Stiglitz, J. and A. Weiss, 1983, 'Incentive Effects of Terminations: Applications to the Credit and Labour Markets', American Economic Review, 73, 912-927.

Storey, D. J., 1994, 'New Firm Growth and Bank Financing', Small Business Economics, 6, 139-150.

Storey, D.J. and B. Tether, 1996, Review of the Empirical Knowledge and an Assessment of Statistical Data on the Economic Importance of new Technology Based Firms, Country Report for Great Britain, Coventry.

Van Praag, M., 2003, 'Initial Capital Constrains Hinder Entrepreneurial Performance: An Empirical Analysis‘. CESifo Working Paper Series No. 887.

Wagner, J., 2007, 'What a Difference a Y makes - Female and Male Nascent Entrepreneurs in Germany', Small Business Economics 28, 1-21.

Webb, D.C., 1991, ,Long-Term Financial Contracts can Mitigate the Adverse Selection Problem in Project Financing', International Economic Review, 32, 305-320.

Werner, A., 2007, Entrepreneurial Signaling, Munich, Rainer Hammp.

Werner, A., and R. Kay, 2006, 'Unternehmensgründungen durch zuvor gescheiterte Unternehmer: Empirische Relevanz und Erfolgschancen von Restartern'. In: Achleitner, A-K., Klandt, H., Koch, L.T. and K.-I. Voigt (eds.), Jahrbuch Entrepreneurship 2005/2006 - Gründungsforschung und Gründungsmanagement, Heidelberg, Springer Verlag, 157-185.

Wolfe, R. and W. Gould, 1998, An Approximate Likelihood-Ratio Test for Ordinal Response Models, Stata Technical Bulletin, 42, 24-27.

Wolpin, K. I., 1977, 'Education and Screening', American Economic Review, 67, 949-958.

\footnotetext{
i Asymmetric information and adverse selection does not necessarily result in credit rationing. And credit constraints do not always imply inefficiency or market failure (Stiglitz and Weiss, 1983; Besanko and Thakor, 1987). De Meza and Webb (1987) for example propose a model with assumptions similar to those of the most influential credit rationing model of Stiglitz and Weiss (1981), but with the opposite effects; i.e. over-investment and too much entrepreneurship instead of credit rationing. However, the majority of studies assumes credit rationing and analyze either Type I rationing (rationing via loan size) or Type II rationing (rationing via selection of loan applicants) and their negative consequences such as a shortage of start-ups.

ii However, tighter constraints might still not be inefficient. They might decrease profits of entrepreneurs, but this does not necessarily imply inefficiency or market failure (Parker and van Praag 2005) because borrowing constraints can be an efficient market reaction. On the other hand, if one assumes positive externalities like innovation spillovers, which are often shown to be important in a regional context, credit restrictions might become a problem and could justify government intervention to relax them - but only in special cases.

iii The data were collected with financial support from the German National Science Foundation (DFG) under project number STE 628/5-1, the German Founder Bank (Deutsche Ausgleichsbank, DtA) and the Cologne Savings Bank. I thank Petra Moog and Güldem Demirer for introducing us to their dataset.

iv Since our subjective rating refers to credit problems in obtaining the initial credit during the start-up phase, there is no need to control for performance variables as would be the case if we asked about credit problems in an already running company. Hence typical endogeneity problems connected with entering performance variables in a credit constraints regression are also avoided.

"The dependent variable "credit problems" is ordinal which makes OLS regressions inappropriate.

${ }^{v i}$ Before discussing interpretation, it is important to test the parallel regression assumption which is implicit in ordinal regression models (see Long and Freese, 2003). Without going into details, we test the assumption by running an approximate LR test (Wolf and Gould, 1998). Fortunately, in our empirical models the parallel regression assumption is not violated.
} 